\title{
Weight gain and reduced energy expenditure in low-income Brazilian women living in slums: a 4-year follow-up study
}

\author{
Telma M. M. T. Florêncio ${ }^{1 *}$, Nassib B. Bueno ${ }^{2}$, Ana P. G. Clemente ${ }^{1}$, Fabiana C. A. Albuquerque $^{1}$, \\ Revilane P. A. Britto ${ }^{1}$, Eduardo Ferriolli ${ }^{3}$ and Ana L. Sawaya ${ }^{2}$ \\ ${ }^{1}$ Centro de Recuperação e Educação Nutricional, Faculdade de Nutrição, Universidade Federal de Alagoas, Conjunto \\ Denisson Menezes s/n. Tabuleiro do Martins, 57080-000 Maceió, AL, Brazil \\ ${ }^{2}$ Laboratório de Fisiologia da Nutrição, Departamento de Fisiologia, Universidade Federal de São Paulo, Rua Botucatu 862, \\ Edificio de Ciências Biomédicas, Vila Clementino 04023-060, São Paulo, SP, Brazil \\ ${ }^{3}$ Departamento de Clinica Médica, Universidade de São Paulo, Faculdade de Medicina de Ribeirão Preto, \\ Avenida Bandeirantes, 3900, Monte Alegre, Ribeirão Preto, CEP 140499-000, SP, Brazil
}

(Submitted 21 November 2014 - Final revision received 11 April 2015 - Accepted 29 April 2015 - First published online 30 June 2015)

\section{Abstract}

The present study aimed to investigate the possible changes in anthropometric and biochemical parameters in low-income women living in the outskirts of Maceió (northeast Brazil), and to explore the possible role of dietary intake and physical activity in these changes. A prospective longitudinal study was conducted in a cohort of mothers of malnourished children who attended the Center for Nutritional Recovery and Education, an outreach programme of the Federal University of Alagoas. Socio-economic, anthropometric, biochemical and dietary intake data were assessed at baseline and after a follow-up period of 4 years. Energy expenditure (using doubly labelled water) and physical activity (using triaxial accelerometers) were assessed only in a subgroup of women after 4 years. A total of eighty-five women were assessed. Participants showed an altered biochemical profile, increased systolic blood pressure, decreased thyroid hormone levels, and body-weight gain. However, dietary intakes of the participants did not include large quantities of highly processed and high-glycaemic index foods. The energy intake of the participants did not differ from their total energy expenditure (7990.3 (7173.7-8806.8) v. 8798.1 (8169.0-9432.4) kJ, respectively; $P=0.084)$. Multivariate analyses showed a significant effect of time spent watching television ( $\beta=0.639$ ( 0.003 to 1.275$) ; P=0.048)$ and dietary diversity score ( $\beta=-1.039(-2.010$ to -0.067$) ; P=0.036$ ) on weight gain. The present study indicates that poor women, who are mothers of malnourished children and have a reasonably balanced dietary intake, exhibit weight gain and are at risk of developing chronic diseases.

Key words: Weight gain: Energy expenditure: Thyroid hormone: Physical activity: Dietary intake

The growing epidemic of obesity, which is also observed among the poor in developing countries, such as Brazil, has led researchers to question the true causes of this weight gain for the purpose of implementing effective prevention and treatment strategies ${ }^{(1-3)}$. Much of the disease burden in adulthood, which implies damage to human development and national economies, can partly be prevented by lifestyle changes, such as diet and physical $\operatorname{activity}^{(4-7)}$. Obesity is often associated with poor dietary habits; therefore, recent studies have investigated the relationship between increased consumption of processed foods and weight gain ${ }^{(8-10)}$.

Using this rationale, it is likely that the increased incidence of obesity in the primitive populations of the Americas and
Canada is associated with changes in their eating habits ${ }^{(11)}$. In the past, these people consumed natural foods such as fish, meat, wild plants and fruits. However, in the course of time, they transitioned to the contemporary eating pattern, which is based on processed flour (breads, pasta and cakes), cassava flour and maize (couscous, polenta and crackers), and foods with a high glycaemic index and load ${ }^{(12)}$, which may cause metabolic alterations. These alterations cause the body to remain in a 'glucocentric' state (i.e. constantly using glucose as an energy source), leading to frequent lipogenesis and weight gain ${ }^{(13,14)}$. Lifestyle changes may also explain the increased incidence of obesity among developing countries in recent decades, such as an increased intake of processed foods with high levels of carbohydrates and

Abbreviations: BP, blood pressure; DLW, doubly labelled water; PAL, physical activity level; TEE, total energy expenditure; TV, television. 
fats and a sedentary lifestyle, a process known as nutrition transition $^{(15)}$

In addition, epigenetic changes due to malnutrition during prenatal growth and early childhood may play a role in the development of obesity in low-income populations ${ }^{(16)}$. This condition may induce growth retardation and energy-sparing mechanisms, such as impaired fat oxidation, decreased resting expenditure and low physical activity ${ }^{(17)}$. The first insights regarding this theory is known as the 'Barker hypothesis', which states that fetal undernutrition in middle to late gestation programmes later $\mathrm{CHD}^{(18)}$. Thereafter, studies have suggested that early life events, which determine in part the risk of later disease, occur not only in the fetal period specifically, but also throughout the plastic phase of development, a process also known as the Developmental Origins of Health and Disease ${ }^{(19)}$. More recently, the intergenerational hypothesis has regained space. This hypothesis states that maternal disadvantage leads to worse health at birth through poor health behaviours, such as exposure to harmful environmental factors, worse access to medical care, including family planning, and worse underlying maternal health ${ }^{(20)}$.

In Brazil, excess weight can be found in all social classes. In populations similar to that of the present study, it has been observed that the prevalence of excess weight is higher among short-statured women in the lower quintile of income (a possible sequela of malnutrition in early life, especially in a poor socio-economic environment). In this particular group, the prevalence of overweight increased from $35 \%$ in 2001 to $56.5 \%$ in $2009^{(21-23)}$. The increased prevalence of obesity has been associated with increased risk factors for developing CVD, such as high levels of cholesterol, reduced glucose tolerance and increased prevalence of hypertension ${ }^{(24-27)}$. These factors influence the incidence of morbidity and mortality worldwide; approximately twothirds of global deaths are due to chronic diseases ${ }^{(28)}$. In Brazil, the number of obesity-related deaths has more than tripled in 10 years. Furthermore, the cost of hospitalisation and medicines associated with this condition exceeded half a billion US dollars in $2013^{(29)}$.

Therefore, we performed a prospective study on poor women living in slums who were followed up for a period of 4 years. The dietary intake, biochemical profile, energy expenditure and physical activity level (PAL) of these women were measured. The objectives of the present study were to assess the changes in the aforementioned parameters in women living in a poor socio-economic environment, and to explore the influence of their dietary intake and physical activity patterns on these changes.

\section{Methods \\ Participants and study design}

The present longitudinal study, with 4 years of follow-up, was performed from June 2009 to July 2013 in women living in the slums of Maceió-AL in northeast Brazil. These women were mothers of malnourished children who attended the Center for Nutritional Recovery and Education/Maceió (CREN), an advanced campus at the Federal University of Alagoas (UFAL). Sample size was determined based on the number of mothers ( $n$ 100) with their children in the day-hospital system at the Center (i.e. the physical capacity of the Center). All mothers aged between 18 and 45 years who were affiliated with the CREN and who attended monthly meetings at the Center were included in the study. Pregnant women and women with anatomical deformities and/or prostheses that might interfere with anthropometric measurements were excluded. Initially, a total of eighty-eight women were assessed.

\section{Measurements}

All data were collected from the entire cohort on two different occasions, at baseline and at the end of the follow-up ( 4 years), except for total energy expenditure (TEE) data, measured using the doubly labelled water (DLW) technique, and PAL data, measured with triaxial accelerometers. Participants were subjected to the assessment of the following clinical and anthropometric variables: body weight; height; waist and hip circumference; blood pressure (BP). Blood was collected from the participants for biochemical analyses. Dietary intake data were analysed using the $24 \mathrm{~h}$ recall method on three separate days. TEE and PAL were assessed only in a subgroup of women ( $n$ 44) at the end of the follow-up period due to the high costs and methodological requirements of these variables. Similarly, dietary intake data were measured only in the same subgroup at the end of the follow-up period. This subgroup had similar anthropometric and socio-economic characteristics (education, income, height, age, weight and BMI) to those of the total sample.

\section{Socio-economic data}

Data collection for socio-economic analysis was made at the CREN using an individual protocol that contained structured questions about the participants' housing conditions, number of family members, family incomes, employment and education.

\section{Anthropometric data}

Anthropometric measurements were obtained while the women were barefoot and wearing light clothing. Body weight was measured using a Marte ${ }^{\circledR}$ PP180 electronic scale with $180 \mathrm{~kg}$ capacity and $100 \mathrm{~g}$ precision. Height was measured while the women stood in the upright position, using a portable stadiometer with a non-extensible tape and a sensitivity of $0.1 \mathrm{~cm}$. Waist circumference was obtained during normal expiration at the midpoint between the iliac crest and the last rib. Hip circumference was measured at the point of maximum circumference over the buttocks, with the tape held flat horizontally without pressing the soft tissue. Current nutritional status was defined by the BMI (weight $(\mathrm{kg}) /$ height $^{2}\left(\mathrm{~m}^{2}\right)$ ), which was classified according to the recommendations of the World Health Organization ${ }^{(30)}$. 


\section{Metabolic and biochemical data}

BP was measured at the beginning and end of the study using OMRON digital monitors (model HEM-421-CO) that were calibrated weekly against mercury manometers. The measurements were repeated three consecutive times, with the participants seated after a 5 min rest, according to the Sixth Report of the Joint National Committee (USA) ${ }^{(31)}$ Regarding the biochemical profile, blood samples were taken at the beginning and at the end of the study. The participants fasted for $12 \mathrm{~h}$ before the blood sample collection. The samples were collected via venepuncture at the CREN. The following tests were performed by an accredited clinical laboratory: blood glucose and fasting insulin; homeostasis model assessment for insulin resistance (HOMA-IR); HOMA- $\beta$ for $\beta$-cell function; lipid profile (total cholesterol, HDL-cholesterol, LDL-cholesterol and TAG), aspartate transaminase; alanine transaminase; $\gamma$-glutamyl transpeptidase (GGT); thyroid hormones (thyroid-stimulating hormone; triiodothyronine).

HOMA-IR was calculated as follows ${ }^{(32)}$ :

$$
\begin{aligned}
\text { HOMA-IR }= & (\text { fasting blood glucose }(\mathrm{mg} / \mathrm{dl}) \\
& \times \text { fasting insulin }(\mu \mathrm{U} / \mathrm{ml})) / 22 \cdot 5 .
\end{aligned}
$$

HOMA- $\beta$ was derived as follows ${ }^{(32)}$ :

$$
\begin{aligned}
\operatorname{HOMA}-\beta(\%)= & (20 \times \text { fasting insulin }(\mu \mathrm{U} / \mathrm{ml})) / \\
& (\text { fasting blood glucose }(\mathrm{mg} / \mathrm{dl})-3 \cdot 5) .
\end{aligned}
$$

LDL-cholesterol values were calculated using a standardised procedure $^{(33)}$

To convert insulin in $\mu \mathrm{U} / \mathrm{ml}$ to $\mathrm{pmol} / \mathrm{l}$, multiply by 6.945 ; to convert glucose in $\mathrm{mg} / \mathrm{dl}$ to $\mathrm{mmol} / \mathrm{l}$, multiply by 0.0555 .

\section{Dietary intake data}

To assess dietary intake, three $24 \mathrm{~h}$ recall questionnaires were used on random days, including a weekend day, by means of a photographic food manual ${ }^{(34)}$, widely used in Brazilian research. To calculate energy and macronutrient intake, the Nutwin (Federal University of São Paulo) software was used. To assess macronutrient intake adequacy, the estimated average requirement method from the National Research Council was employed ${ }^{(35)}$

To classify foods according to their processing level, the parameters described by Monteiro et $a l^{(36)}$ were used. Foods were classified into three groups as follows: group 1, in natura or minimally processed foods; group 2 , processed culinary ingredients; group 3 , ready-to-consume, ultraprocessed foods.

To determine the glycaemic index of the consumed meals, the Food and Agriculture Organization/WHO Expert Consultation Protocol was followed. The meals were given a low $(\leq 55)$, moderate $(56-69)$ or high-glycaemic index $(\geq 70)$ rating $^{(37)}$.

In addition, we calculated the dietary diversity score, according to the Food and Agriculture Organization guidelines ${ }^{(38)}$. Briefly, this tool summarises all food products consumed by the individuals into twelve different groups (cereals; roots and tubers; vegetables; fruits; meats; eggs; fish and seafood; legumes, nuts and seeds; milk and milk products; oils and fats; sweets; spices and condiments), and yields a value ranging from 0 to 12 , where 0 represents absence of diversity and 12 represents plenty of diversity.

\section{Total energy expenditure}

To measure TEE, the DLW technique $\left({ }^{2} \mathrm{H}_{2}{ }^{18} \mathrm{O}\right)$ was used. On the first day of the study, we collected a urine sample from each woman in the morning after a $12 \mathrm{~h}$ fast. Then, the volunteers were orally administered a mixture of $0 \cdot 12 \mathrm{~g}{ }^{2} \mathrm{H}_{2} \mathrm{O}$ (99.8\% excess atoms) per kg body water and $2 \mathrm{~g}^{2} \mathrm{H}_{2}{ }^{18} \mathrm{O}$ standard (10\% excess atoms) per kg body water. After $30 \mathrm{~min}$, they received a standard breakfast. Urine samples were collected once per $\mathrm{d}$ for a period of $14 \mathrm{~d}$ in the homes of the volunteers. These samples were collected at the same time each day. The samples were frozen $\left(-20^{\circ} \mathrm{C}\right)$ and then transported to the Department of Human Nutrition/ Clinical Medicine, University of São Paulo - Ribeirão Preto for analysis.

For the analysis, ${ }^{2} \mathrm{H}_{2}{ }^{18} \mathrm{O}$ was prepared for isotopic weighing $\left({ }^{2} \mathrm{H} /{ }^{1} \mathrm{H}\right.$ and $\left.{ }^{18} \mathrm{O}_{2} /{ }^{16} \mathrm{O}_{2}\right){ }^{(39)}$ and then analysed with extremeprecision MS (Hydra System HIP 20-20; Europa Scientific). The collected data were analysed with DLW Software using the standard calculation procedures of the International Dietary Energy Consulting Group.

\section{Physical activity level}

To measure PAL, triaxial accelerometers (activPAL ${ }^{\circledR}$ ) were used. The accelerometers were fixed on the volunteers' thighs, where the stickers remained for seven consecutive days. The devices monitored all activities that were performed during the day, and registered the intensity and duration of each category of activity, yielding a coefficient of the individual's PAL. The categories of PAL were defined as sedentary (PAL $\geq 1.0<1.4$ ), low active $(\mathrm{PAL} \geq 1.4<1.6$ ), active $(\mathrm{PAL} \geq 1.6<1.9)$ and very active (PAL $\geq 1.9<2.5)$ according to the Institute of Medicine ${ }^{(35)}$

\section{Ethical aspects}

Data were collected only after the participants provided written consent. The present study was approved by the Ethics Research Committee of the Federal University of Alagoas (no. 20090132001-6).

\section{Statistical analyses}

Categorical data are presented as absolute and relative frequencies, and continuous data are presented as means and $95 \%$ CI. McNemar's test was used to assess the differences between the baseline and follow-up measurements of categorical variables, and the paired-samples $t$ test was used for continuous variables. Homogeneity of variance for these variables was tested using Levene's test. 
To assess the influence of independent variables on weight gain during the 4 years of follow-up, multivariate linear regression analyses were used, controlling for socio-economic variables. For all analyses, an $\alpha$ value of $5 \%$ was used. All statistical analyses were performed using SPSS version 20.0 (IBM Statistics).

\section{Results}

Of the eighty-eight women initially assessed at baseline, eighty-five were reassessed at the end of the follow-up. Therefore, data are presented for these eighty-five women. TEE, PAL and dietary intake data were measured only in a subgroup of women ( $n$ 44) at the end of the follow-up. The mean age of the participants was $27.8(26.5-29 \cdot 05)$ years, and $43 \%$ of the women were born in rural areas in the state. The mean years of education of the women was $<6$ years, and $82 \%$ were functionally illiterate or had only a primary education. Over $80 \%$ of the women were housewives. The average height of the cohort was $1.54 \mathrm{~m}$, ranking them in the seventh percentile of the WHO's growth curves. The mean PAL was classified as 'low activity', according to the Institute of Medicine, with more than $3 \mathrm{~h}$ spent watching television (TV) daily, and a TEE of $8798 \cdot 1 \mathrm{~kJ} / \mathrm{d}$ was recorded (Table 1). Regarding housing, $40 \%$ of the participants lived in brick houses without floors and/or wall coverings, with an average of four rooms housing five people. There were no significant changes in these data during the 4 years of follow-up. The significant increase in the per capita income (US $\$ 1.73 / \mathrm{d}$ per capita at baseline) was accompanied by the increased coverage of the Bolsa Família Program, a federal government's cash transfer programme, which covered $72 \%$ in 2009 and $95 \%$ in 2013 (Table 1). Although the coverage and the mean value of the benefit increased, the percentage of the benefit in the total income decreased during the follow-up period.

The analyses of dietary intake data showed a non-significant increase in energy intake (approximately $753.4 \mathrm{~kJ}$ ) during the 4 years of follow-up (Table 2). There were no differences between the mean daily energy intake at baseline and the intake at the end of the follow-up. These values were lower than those of TEE estimated by the DLW technique. However, the paired-samples $t$ test conducted between the mean final energy intake and TEE including only the subgroup ( $n$ 44) subjected to the DLW technique did not show significant differences $(7990 \cdot 3 \quad(7173 \cdot 7-8806 \cdot 8) \quad v$. $8798 \cdot 1$ (8169.0-9432.4) kJ, respectively; $P=0.084$ ). In addition, the variety of foods consumed was low, as shown by the dietary diversity score analysis.

Table 3 presents the anthropometric and biochemical characteristics at baseline and after 4 years of follow-up. Between the beginning and the end of the study, significant increases were observed in weight, BMI, and waist and hip circumference. Weight gain did not differ between women with excess weight $\left(\mathrm{BMI}>25 \mathrm{~kg} / \mathrm{m}^{2}\right)$ at baseline and those without excess weight $(4 \cdot 7(3 \cdot 16-6 \cdot 41) \mathrm{kg}, n 43 v \cdot 2 \cdot 8$ $(0.98-4.77) \mathrm{kg}, n$ 42, respectively; $P=0 \cdot 126)$. Regarding the biochemical profile, a significant increase in the levels of glucose, TAG, total cholesterol and aspartate transaminase and a decreased sensitivity of $\beta$-cell were observed. Furthermore, thyroid hormone levels (triiodothyronine) decreased significantly and systolic BP increased.

Using weight gain as the dependent variable and dietary intake and physical activity data as independent variables,

Table 1. Socio-economic data of the cohort at the beginning and at the end of the follow-up period

(Number of participants and percentages; mean values and 95\% confidence intervals)

\begin{tabular}{|c|c|c|c|c|c|}
\hline \multirow[b]{2}{*}{ Variables } & \multicolumn{2}{|c|}{ Baseline } & \multicolumn{2}{|c|}{ Final } & \multirow[b]{2}{*}{$P^{\star}$} \\
\hline & $n$ & $\%$ & $n$ & $\%$ & \\
\hline Age (years) & & & & & $<0.01$ \\
\hline Mean & \multicolumn{2}{|c|}{$27 \cdot 8$} & \multicolumn{2}{|c|}{31.8} & \\
\hline $95 \% \mathrm{Cl}$ & \multicolumn{2}{|c|}{$26 \cdot 6,29 \cdot 0$} & \multicolumn{2}{|c|}{$30 \cdot 6,33 \cdot 0$} & \\
\hline Height $(\mathrm{cm})$ & & & - & - & - \\
\hline Mean & \multicolumn{2}{|c|}{$154 \cdot 1$} & & & \\
\hline $95 \% \mathrm{Cl}$ & \multicolumn{2}{|c|}{$\begin{array}{r}152 \cdot 6 \\
155 \cdot 4\end{array}$} & & & \\
\hline Born in the countryside & 37 & $43 \cdot 6$ & - & - & - \\
\hline Masonry house & 83 & $97 \cdot 6$ & 85 & 100 & 0.362 \\
\hline House with a coated floor & 35 & $41 \cdot 2$ & 40 & 47 & 0.145 \\
\hline Number of rooms & & & & & 0.139 \\
\hline Mean & \multicolumn{2}{|c|}{3.6} & \multicolumn{2}{|c|}{3.8} & \\
\hline $95 \% \mathrm{Cl}$ & \multicolumn{2}{|c|}{$3 \cdot 4,3 \cdot 8$} & \multicolumn{2}{|c|}{$3 \cdot 6,4 \cdot 0$} & \\
\hline Married/stable union & 63 & $75 \cdot 6$ & 67 & $78 \cdot 8$ & 0.863 \\
\hline Years of schooling & & & & & 0.102 \\
\hline Mean & \multicolumn{2}{|c|}{$5 \cdot 1$} & \multicolumn{2}{|c|}{$5 \cdot 3$} & \\
\hline $95 \% \mathrm{Cl}$ & \multicolumn{2}{|c|}{$4 \cdot 5,5 \cdot 8$} & \multicolumn{2}{|c|}{$4 \cdot 6,5 \cdot 9$} & \\
\hline \multicolumn{6}{|l|}{ Schooling: } \\
\hline Illiterate & 8 & $9 \cdot 4$ & 7 & 8 & 0.123 \\
\hline Read and write & 13 & $15 \cdot 3$ & 6 & 7 & \\
\hline $4-8$ years & 52 & $61 \cdot 2$ & 58 & $68 \cdot 2$ & \\
\hline $8-11$ years & 12 & $14 \cdot 1$ & 17 & 20 & \\
\hline Unemployed & 71 & 83.5 & 70 & $82 \cdot 3$ & 0.915 \\
\hline Receiving government benefits & 61 & $71 \cdot 8$ & 81 & $95 \cdot 2$ & $<0.01$ \\
\hline Benefit value (US\$/month)† & & & & & 0.408 \\
\hline Mean & & & & & \\
\hline $95 \% \mathrm{Cl}$ & 60 . & $68 \cdot 2$ & 58 . & $68 \cdot 2$ & \\
\hline Total house income (US\$/month) & & & & & $<0.01$ \\
\hline Mean & & & & $7 \cdot 8$ & \\
\hline $95 \% \mathrm{Cl}$ & & $\begin{array}{l}2, \\
9 \cdot 1\end{array}$ & & $\begin{array}{l}4 \cdot 6, \\
1 \cdot 1\end{array}$ & \\
\hline Income per capita (US\$) & & & & & $<0.01$ \\
\hline Mean & & & & & \\
\hline $95 \% \mathrm{Cl}$ & 44 . & 59.9 & 69 . & $84 \cdot 8$ & \\
\hline Benefit/income (\%)† & & & & & $<0.01$ \\
\hline Mean & & & & & \\
\hline $95 \% \mathrm{Cl}$ & 32 . & $48 \cdot 9$ & 17 & 24.5 & \\
\hline Household members & & & & & $0 \cdot 807$ \\
\hline Mean & & & & & \\
\hline $95 \% \mathrm{Cl}$ & & 5.5 & & $5 \cdot 4$ & \\
\hline BMI classification $\left(\mathrm{kg} / \mathrm{m}^{2}\right)$ & & & & & \\
\hline Underweight & 1 & $1 \cdot 2$ & 1 & $1 \cdot 2$ & $<0.01$ \\
\hline Normal weight & 42 & $49 \cdot 4$ & 27 & $31 \cdot 8$ & \\
\hline Overweight & 26 & $30 \cdot 6$ & 30 & $35 \cdot 3$ & \\
\hline Obese & 16 & $18 \cdot 8$ & 27 & $31 \cdot 8$ & \\
\hline Metabolic syndrome & 11 & $12 \cdot 9$ & 12 & $14 \cdot 1$ & 0.999 \\
\hline Time spent watching television (h) & & & & & 0.880 \\
\hline Mean & & & & & \\
\hline $95 \% \mathrm{Cl}$ & 2.9 & 3.79 & $2 \cdot 9$ & $3 \cdot 76$ & \\
\hline Total energy expenditure $(\mathrm{kJ} / \mathrm{d})$ & - & - & & & - \\
\hline Mean & & & & $8 \cdot 1$ & \\
\hline $95 \% \mathrm{Cl}$ & & & & $\begin{array}{l}9 \cdot 0, \\
32 \cdot 4\end{array}$ & \\
\hline Physical activity level & - & - & & & - \\
\hline Mean & & & & & \\
\hline $95 \% \mathrm{Cl}$ & & & 1.4 & 1.48 & \\
\hline
\end{tabular}

* $P$ value was obtained using the paired-samples $t$ test or McNemar's test. †Analysis included only the sixty-one individuals who received benefit at the baseline and at the end of the follow-up period. 
Table 2. Dietary intake data for the entire cohort at the beginning and for the subgroup at the beginning and at the end of the followup period

(Mean values and $95 \%$ confidence intervals)

\begin{tabular}{|c|c|c|c|c|c|c|c|}
\hline \multirow[b]{2}{*}{ Variables } & \multicolumn{2}{|c|}{ Baseline ( $n$ 85) } & \multicolumn{2}{|c|}{ Baseline ( $n$ 44) } & \multicolumn{2}{|c|}{ Final ( $n$ 44) } & \multirow[b]{2}{*}{$P^{\star}$} \\
\hline & Mean & $95 \% \mathrm{Cl}$ & Mean & $95 \% \mathrm{Cl}$ & Mean & $95 \% \mathrm{Cl}$ & \\
\hline Meals/d & 3.79 & $3.59,3.99$ & $3 \cdot 88$ & $3.57,4.19$ & 4.00 & $3.74,4.25$ & 0.462 \\
\hline Dietary diversity score & $6 \cdot 41$ & $6 \cdot 12,6 \cdot 69$ & $6 \cdot 20$ & $5 \cdot 84,6.56$ & $6 \cdot 38$ & $6 \cdot 04,6 \cdot 72$ & 0.185 \\
\hline Energy intake (kJ) & $7268 \cdot 3$ & $6795 \cdot 0,7742 \cdot 8$ & $7242 \cdot 0$ & $6518 \cdot 9,7965 \cdot 0$ & $7990 \cdot 3$ & $7173 \cdot 7,8806 \cdot 8$ & 0.098 \\
\hline Energy intake $(\mathrm{kJ} / \mathrm{kg})$ & $122 \cdot 3$ & $112 \cdot 1,132 \cdot 4$ & 124.9 & $109 \cdot 3,140 \cdot 3$ & $126 \cdot 5$ & $110 \cdot 9,142 \cdot 1$ & 0.840 \\
\hline Proteins (g) & 69.53 & $64 \cdot 66,74.41$ & $70 \cdot 60$ & $63 \cdot 39,77 \cdot 82$ & 79.60 & $68.55,90 \cdot 66$ & 0.159 \\
\hline Proteins $(\mathrm{g} / \mathrm{kg})$ & 1.19 & $1.08,1.29$ & 1.21 & $1.07,1.36$ & 1.24 & $1.05,1.43$ & 0.789 \\
\hline Proteins (\%) & $16 \cdot 31$ & $15 \cdot 47,17 \cdot 16$ & $16 \cdot 67$ & $15 \cdot 53,17 \cdot 80$ & $16 \cdot 70$ & $15.49,17.90$ & 0.975 \\
\hline Carbohydrates (g) & $253 \cdot 84$ & $235.64,272.05$ & $254 \cdot 33$ & $227 \cdot 17,281 \cdot 49$ & $269 \cdot 75$ & $237 \cdot 15,302 \cdot 36$ & 0.394 \\
\hline Carbohydrates (\%) & 58.64 & $57 \cdot 14,60 \cdot 14$ & 58.87 & $57.05,60.69$ & 56.33 & $53.65,59.00$ & 0.105 \\
\hline Lipids (g) & 48.92 & $44 \cdot 52,53 \cdot 32$ & 48.83 & $41.98,55.68$ & $56 \cdot 33$ & $49 \cdot 47,63 \cdot 18$ & 0.059 \\
\hline Lipids (\%) & 24.95 & $23 \cdot 60,26 \cdot 31$ & 24.46 & $22 \cdot 60,26 \cdot 31$ & $26 \cdot 96$ & $24 \cdot 88,29 \cdot 05$ & 0.063 \\
\hline
\end{tabular}

${ }^{*} P$ value was obtained using the paired-samples $t$ test $(n 44)$.

controlling for socio-economic characteristics, the multivariate linear regression analysis showed that only the variables time spent watching TV and dietary diversity score exhibited a significant effect on weight gain (Table 4) . As a sensitivity analysis, we performed a multivariate regression analysis of PAL and TEE against weight gain within the subgroup of women ( $n$ 44), controlling for socio-economic factors. The analysis revealed that only PAL exhibited a significant effect ( $\beta=-24.79$ ( -48.12 to -1.467$) ; P=0.038$ ). Table 5 presents the glycaemic index and the processing level of the main foods that the study population consumed, indicating a monotonous food intake pattern. The hypothesis that the intake of high-glycaemic index and ultra-processed foods was associated with weight gain was not confirmed.

\section{Discussion}

The average stature of the study cohort ranged from the 1.5 th percentile $(1.49 \mathrm{~m})$ to the 25 th percentile $(1.59 \mathrm{~m})$, according to the WHO. It is known that adult height is the result of a combination of genetic and environmental factors. In a study conducted in 473 Brazilian women aged 19 years residing in the city of Pelotas (South Brazil), early life factors such as family income, birth weight and maternal height have been found to be the determinants of adult height ${ }^{(40)}$. The influence of the environment on adult height may be even higher in poor socio-economic settings ${ }^{(41)}$. The mean height of the Pelotas study population was $161 \mathrm{~cm}^{(40)}$, and the median height of the Brazilian women was $160 \mathrm{~cm}^{(29)}$. It must be considered that the women in the present study were born and currently live in a very poor socio-economic environment. Unlike the city of Pelotas, Maceió is a very poor Brazilian city. A probabilistic survey conducted in 1992 showed that stunting levels among children were $22 \cdot 1 \%{ }^{(42)}$, and a survey conducted in the countryside population of the Alagoas state in 1995 found this level to be $39 \cdot 8 \%{ }^{(43)}$. Considering that all women in the present study were born in the Alagoas state before 1995, these data might suggest that these women possibly lived in adverse health and nutritional conditions in early life and, perhaps, failed to reach their full growth potential and development, typically defined as the 50th height percentile of the WHO growth curves ${ }^{(44)}$.

Poverty persisted in the lives of these women, who were semi-illiterate mothers of malnourished children, lived in homes (with an average of five people) without sanitation and had limited financial resources (2.56 US\$/capita per d at the end of the follow-up period). This stratum of income classifies this population as relatively poor, considering the cost of living in Brazil. It is noteworthy that most of the families participated in the federal government's cash transfer programme, with the value of the benefit representing almost $20 \%$ of the family income at the end of the follow-up period. This condition, which links current poverty with possible long-lasting effects of malnutrition, reflected by the short stature of the women, is supported by the fact that the intergenerational transmission of inequality in Brazil is estimated to be among the highest ${ }^{(45)}$.

The women in the present study worsened their metabolic profile during the follow-up period, showing increased body weight, total cholesterol, TAG, fasting blood glucose and systolic BP. A lower socio-economic status increases the risk of developing chronic diseases prematurely, as demonstrated previously in our studies of low-income populations. These studies found a high prevalence of hypertension, dyslipidaemia, insulin resistance and obesity, particularly in women and female adolescents ${ }^{(22,46,47)}$. During the 4 years of followup, the mean income of families increased, together with the coverage of the federal government's cash transfer programme. However, the percentage of the benefit in the total income decreased, indicating that the programme is not solely responsible for the increased income. It is possible that new national policies on minimum wage annual increase could also be responsible for this factor. Studies that investigated similar cash transfer programmes on adult health have shown a positive association between the programme and higher BMI and systolic $\mathrm{BP}^{(48)}$

The weight gain exhibited by the women in the present study is difficult to explain because despite following a 
Table 3. Anthropometric and biochemical data of the cohort at the beginning and at the end of follow-up period (Mean values and $95 \%$ confidence intervals)

\begin{tabular}{|c|c|c|c|c|c|}
\hline \multirow[b]{2}{*}{ Variables } & \multicolumn{2}{|c|}{ Baseline } & \multicolumn{2}{|c|}{ Final } & \multirow[b]{2}{*}{$P^{\star}$} \\
\hline & Mean & $95 \% \mathrm{Cl}$ & Mean & $95 \% \mathrm{Cl}$ & \\
\hline Body weight (kg) & $61 \cdot 7$ & $58 \cdot 8,64 \cdot 5$ & $65 \cdot 5$ & $62 \cdot 6,68 \cdot 4$ & $<0.001$ \\
\hline BMI $\left(\mathrm{kg} / \mathrm{m}^{2}\right)$ & $25 \cdot 9$ & $24 \cdot 8,27 \cdot 0$ & $27 \cdot 5$ & $26 \cdot 4,28 \cdot 7$ & $<0.001$ \\
\hline Waist circumference $(\mathrm{cm})$ & 81.5 & $79 \cdot 0,84 \cdot 1$ & 84.05 & $81 \cdot 5,86 \cdot 6$ & $<0.001$ \\
\hline Hip circumference $(\mathrm{cm})$ & $99 \cdot 1$ & $97 \cdot 0,101 \cdot 3$ & 101.9 & $99.8,104.1$ & $<0.001$ \\
\hline Waist:hip ratio & 0.82 & $0.80,0.83$ & 0.82 & $0.80,0.83$ & 0.583 \\
\hline Waist:height ratio & 0.52 & $0.50,0.54$ & 0.54 & $0.52,0.56$ & 0.003 \\
\hline Systolic blood pressure (mmHg) & 114.33 & $111 \cdot 8,116 \cdot 8$ & $118 \cdot 3$ & $115 \cdot 7,120 \cdot 8$ & $<0.001$ \\
\hline Diastolic blood pressure $(\mathrm{mmHg})$ & 74.4 & $72 \cdot 2,76 \cdot 6$ & $74 \cdot 1$ & $72 \cdot 1,76 \cdot 0$ & 0.701 \\
\hline Fasting blood glucose & & & & & $<0.001$ \\
\hline $\mathrm{mg} / \mathrm{dl}$ & $69 \cdot 7$ & $67 \cdot 9,71 \cdot 5$ & 75.4 & $73 \cdot 5,77.3$ & \\
\hline $\mathrm{nmol} / \mathrm{l}$ & 3.9 & $3 \cdot 8,4 \cdot 0$ & $4 \cdot 2$ & $4 \cdot 1,4 \cdot 3$ & \\
\hline Insulin & & & & & 0.198 \\
\hline $\mathrm{mUI} / \mathrm{l}$ & 8.4 & $6 \cdot 6,10 \cdot 1$ & 7.5 & $6 \cdot 3,8 \cdot 8$ & \\
\hline $\mathrm{pmol} / \mathrm{l}$ & $58 \cdot 3$ & $45 \cdot 8,70 \cdot 1$ & $52 \cdot 1$ & $43 \cdot 8,61 \cdot 1$ & \\
\hline HOMA-IR & 1.0 & $0.80,1.20$ & 0.93 & $0.78,1.08$ & 0.341 \\
\hline HOMA- $\beta$ (\%) & $160 \cdot 3$ & $140 \cdot 3,180 \cdot 2$ & $130 \cdot 3$ & $115 \cdot 4,145 \cdot 1$ & $<0.001$ \\
\hline Total cholesterol & & & & & 0.034 \\
\hline $\mathrm{mg} / \mathrm{dl}$ & $176 \cdot 4$ & $169 \cdot 1,184 \cdot 1$ & 183.3 & $175 \cdot 7,190 \cdot 9$ & \\
\hline $\mathrm{mmol} / \mathrm{l}$ & 4.6 & $4 \cdot 4,4 \cdot 8$ & $4 \cdot 7$ & $4.6,4.9$ & \\
\hline HDL-cholesterol & & & & & 0.989 \\
\hline $\mathrm{mg} / \mathrm{dl}$ & $48 \cdot 6$ & $46 \cdot 5,50 \cdot 8$ & $48 \cdot 6$ & $46 \cdot 7,50 \cdot 5$ & \\
\hline $\mathrm{mmol} / \mathrm{l}$ & 1.3 & $1 \cdot 2,1 \cdot 3$ & 1.3 & $1 \cdot 2,1 \cdot 3$ & \\
\hline LDL-cholesterol & & & & & 0.513 \\
\hline $\mathrm{mg} / \mathrm{dl}$ & $110 \cdot 3$ & $103 \cdot 3,117 \cdot 3$ & $112 \cdot 2$ & $105 \cdot 8,118 \cdot 5$ & \\
\hline $\mathrm{mmol} / \mathrm{l}$ & 2.9 & $2 \cdot 7,3 \cdot 0$ & $2 \cdot 9$ & $2 \cdot 7,3 \cdot 1$ & \\
\hline TAG & & & & & $<0.001$ \\
\hline $\mathrm{mg} / \mathrm{dl}$ & 91.5 & $80 \cdot 9,102 \cdot 1$ & $113 \cdot 4$ & $99 \cdot 0,127 \cdot 8$ & \\
\hline $\mathrm{mmol} / \mathrm{l}$ & 1.0 & $0.9,1.2$ & 1.3 & $1 \cdot 1,1.4$ & \\
\hline Aspartate aminotransferase $(\mathrm{U} / \mathrm{l}) \dagger$ & $17 \cdot 8$ & $16 \cdot 8,18 \cdot 8$ & $24 \cdot 1$ & $22 \cdot 7,25 \cdot 5$ & $<0.001$ \\
\hline Alanine aminotransferase $(\mathrm{U} / \mathrm{l}) \dagger$ & $17 \cdot 01$ & $14 \cdot 9,19 \cdot 0$ & $19 \cdot 2$ & $17 \cdot 0,21 \cdot 4$ & 0.07 \\
\hline$\gamma$-Glutamyl transferase $(\mathrm{U} / \mathrm{l}) \dagger$ & $25 \cdot 4$ & $22 \cdot 0,28 \cdot 8$ & $29 \cdot 7$ & $26 \cdot 9,32 \cdot 6$ & 0.008 \\
\hline Free triiodothyronine & & & & & $<0.001$ \\
\hline $\mathrm{ng} / \mathrm{dl}$ & 1.41 & $1.36,1.45$ & 1.24 & $1.18,1.30$ & \\
\hline $\mathrm{nmol} / \mathrm{l}$ & 0.022 & $0.021,0.022$ & 0.019 & $0.018,0.020$ & \\
\hline Thyroid-stimulating hormone $(\mathrm{mUl} / \mathrm{ml})$ & 1.73 & $1.54,1.92$ & 1.64 & $1.42,1.86$ & 0.451 \\
\hline
\end{tabular}

HOMA-IR, homeostasis model assessment for insulin resistance; HOMA- $\beta$, homeostasis model assessment for $\beta$-cell function. ${ }^{*} P$ value was obtained using the paired-samples $t$ test. † To convert to $\mu$ kat/l, multiply by 0.0167 .

monotonous food intake pattern with an average variation of only twenty food products, these women consumed adequate amounts of energy and macronutrients, with $16.5 \%$ of energy derived from protein, $58.6 \%$ from carbohydrate and $24.9 \%$ from fat, in accordance with the current Brazilian recommendations ${ }^{(49)}$. In addition, there was no significant difference in energy and macronutrient intakes between the beginning and the end of the follow-up period. The trend of significantly increased lipid intake at the end of the followup period was somewhat expected because dietary choices are strongly influenced by the taste, cost and convenience, and to a lesser extent by health and variety. The preference for high-fat foods appears to be a universal human trait, and in the absence of efficient physiological mechanisms regulating fat intake, fat consumption appears to be determined simply by the amount of fat available in the food supply ${ }^{(50)}$. In addition, there is evidence that obesity and socio-economic position may be associated with dietary energy density and energy cost, which means that the choice of more energy-dense diets, usually rich in fat, by low-income populations may be an effective way to save money ${ }^{(51)}$. This fact may also explain the low dietary diversity presented by this sample. A systematic review investigating the impact of socio-economic inequalities in food intake among European adults has found that lower socio-economic groups are less likely to consume fruit and vegetables, which have a higher cost and lower energy density ${ }^{(52)}$. Therefore, this dietary intake pattern could contribute to weight gain.

There was also a trend between meal frequency and weight gain. However, there is controversy regarding this issue; for instance, randomised controlled trials have shown a lack of the effect between the two factors ${ }^{(53)}$. Unlike reports in the literature, the intake of foods with high glycaemic index did not appear to influence weight gain ${ }^{(14)}$. Interestingly, these women did not consume significant quantities of ready-toeat, ultra-processed foods. On the contrary, they followed the pattern of the traditional Brazilian meal, such as beans with rice and meat. This finding was also observed by 
Table 4. Multivariate linear regression analyses of changes in body weight (final - baseline values) as the dependent variable

( $\beta$ Coefficients and $95 \%$ confidence intervals)

\begin{tabular}{|c|c|c|c|}
\hline Variables* & $\beta$ & $95 \% \mathrm{Cl}$ & $P$ \\
\hline Time spent watching TV (h) & 0.639 & $0.003,1.275$ & 0.048 \\
\hline Number of meals/d & -1.453 & $-2.932,0.027$ & 0.054 \\
\hline Dietary diversity score & -1.039 & $-2.010,-0.067$ & 0.036 \\
\hline Energy intake $(\mathrm{kcal} / \mathrm{kg})$ & 0.001 & $-0.003,0.002$ & 0.754 \\
\hline Energy intake $(\mathrm{kJ} / \mathrm{kg})$ & 0.000 & $-0.034,0.034$ & 0.754 \\
\hline Proteins $(\mathrm{g} / \mathrm{kg})$ & $1 \cdot 204$ & $-1 \cdot 783,4 \cdot 192$ & 0.425 \\
\hline Carbohydrates (\%) & -0.053 & $-0.238,0.132$ & 0.570 \\
\hline Lipids (\%) & -0.024 & $-0.228,0.181$ & 0.817 \\
\hline High-glycaemic index food intake & $2 \cdot 619$ & $-0.348,5.585$ & 0.083 \\
\hline Medium-glycaemic index food intake & 0.473 & $-1.125,2.071$ & 0.558 \\
\hline Low-glycaemic index food intake & 0.568 & $-1 \cdot 708,2 \cdot 845$ & 0.620 \\
\hline In natura or minimally processed food intake & 0.646 & $-2.233,3.526$ & 0.656 \\
\hline Processed culinary ingredient intake & 0.136 & $-1.536,1.835$ & 0.874 \\
\hline Ready-to-eat or ultra-processed food intake & $2 \cdot 640$ & $-0.940,6 \cdot 220$ & 0.146 \\
\hline Total energy expenditure $\dagger$ & 0.002 & $-0.001,0.006$ & 0.179 \\
\hline Physical activity level $\dagger$ & -24.79 & $-48.12,-1.467$ & 0.038 \\
\hline
\end{tabular}

TV television.

${ }^{*}$ All analyses were controlled for baseline values of age, years of schooling, family income per capita, receiving government benefits, BMI and the metabolic syndrome.

$\dagger$ Analysis included only the subgroup ( $n 44)$ who were subjected to the doubly labelled water technique and triaxial accelerometer testing procedures.

Monteiro et al. ${ }^{(36)}$, who investigated the intake of ultra-processed foods in a sample from the Brazilian Household Budget Survey and found a decreased intake of these foods in the lower-income quintiles of the population.

The weight gain exhibited by the women in the present study may also be associated with their low level of physical activity. Time spent watching TV was significantly associated with weight gain, as revealed by the multivariate analysis. This variable is a common measure of sedentary behaviour, and a systematic review has pointed out that excess TV viewing is associated with reduced physical and psychosocial health, and that reductions in BMI could be achieved with lowering of sedentary time ${ }^{(54)}$. According to the accelerometer analysis, the population had a light PAL, which included domestic chores necessary for activities of daily living. Approximately half of the women resided in rural areas, where these daily and labour activities require greater energy expenditure. Thus, it is likely that physical activity was reduced in these women, thereby allowing increased expressions of the mechanisms of energy conservation, which may partly explain the prevalence of overweight. Also, even after the multivariate analysis, the variable time spent watching TV was associated with weight gain. The sensitivity analyses within the subgroup of forty-four women showed that PAL was significantly associated with weight gain, indicating that sedentarism play an important role in the weight gain of this cohort. Similarly, in a study of stunted preschool children, the higher prevalence of overweight was only associated with their reduced PAL in the context of the nutrition transition $^{(17)}$.

The average energy intake of the women did not change significantly during the follow-up period. Energy intake was lower than TEE measured by the DLW technique. Notably, DLW is the 'gold' standard biomarker used to measure TEE in this type of evaluation. Studies using the DLW technique have shown the limitations of investigating food intake through dietary surveys, such as under-reporting of dietary intake $^{(55)}$. Thus, it is possible that the present study population exhibited this same pattern. The mean TEE of $8798 \cdot 1 \mathrm{~kJ} / \mathrm{d}$ is low compared with that reported in previous studies with similar populations. In a study conducted in the USA, adult women exhibited a mean TEE of $11056.7 \mathrm{~kJ} / \mathrm{d}$ and a total energy intake of $9181.8 \mathrm{~kJ} / \mathrm{d}$. In a study conducted in Brazilian students, teachers and female technicians from a university, the mean TEE was $10969 \cdot 1 \mathrm{~kJ} / \mathrm{d}$ and energy intake was $8551 \mathrm{~kJ} / \mathrm{d}^{(55-57)}$. Even after adjusting for BMI, the women in the present study expended less energy than the women of those studies who were from higher socio-economic levels (present study, $\quad 8798.1 \mathrm{~kJ} / 27.5 \mathrm{~kg} / \mathrm{m}^{2}=319.9 \mathrm{~kJ} \times \mathrm{m}^{2} / \mathrm{kg} \quad v$.

Table 5. Glycaemic index and groups of the processing level of the reported food products consumed

\begin{tabular}{lcc}
\hline Food products & Glycaemic index & $\begin{array}{c}\text { Groups of the } \\
\text { processing level }\end{array}$ \\
\hline High glycaemic index & 72 & 1 \\
Rice & 93 & 1 \\
Cassava flour & 100 & 3 \\
Bread & 109 & 1 \\
Couscous & 78 & 3 \\
Crackers & 87 & 1 \\
Cake & 81 & 1 \\
Cassava & 72 & 3 \\
Industrialised popcorn & 74 & 3 \\
Soft drinks & & \\
Moderate glycaemic index & 69 & 1 \\
Beans & 64 & 1 \\
Pasta & 68 & 2 \\
Coffee with sugar & & 1 \\
Low glycaemic index & 50 & 1 \\
Natural fruit juice & 54 & 1 \\
Fruits (orange and banana) & 27 & 1 \\
Milk & $<20$ & 1 \\
Vegetables (lettuce, carrot, & & 1,3 \\
tomato and onion) & $<15$ & 2 \\
Eggs & $<15$ & \\
Meat (bovine, fish, chicken & & \\
$\quad$ and ultra-processed meats) & $<15$ & \\
Added fats (butter, & & \\
$\quad$ margarine and oils) & & \\
\hline
\end{tabular}


$\left.626 \mathrm{~kJ} / 27 \cdot 9 \mathrm{~kg} / \mathrm{m}^{2}=393.1 \mathrm{~kJ} \times \mathrm{m}^{2} / \mathrm{kg}\right)^{(56)}$. These data show that short-statured women have lower TEE, which corroborates the results found in malnourished children ${ }^{(17,58)}$. This may be attributed to reduced energy intake (i.e. $7990 \cdot 3 \mathrm{~kJ} / \mathrm{d}$ ). Also, given the poor socio-economic environment of the population, it is possible to consider some kind of metabolic adaptation to early malnutrition that led to a decrease in TEE.

This finding of low TEE may also be associated with the significant decrease in triiodothyronine levels that was observed in the present study. Lower triiodothyronine levels decrease thermogenesis and oxygen consumption, which allow for greater energy conservation ${ }^{(59)}$. In addition, Hoffman et al. ${ }^{(60,61)}$ investigated the RMR, TEE, respiratory quotient and substrate oxidation in children with and without short stature, and found that children with short stature had a lower RMR, significantly higher respiratory quotient and, consequently, lower fat oxidation and increased abdominal waist circumference. Changes in waist circumference, particularly in short-statured individuals, are accompanied by metabolic changes in glucose and lipid profiles ${ }^{(7,24)}$. Finally, an increase in systolic BP was also observed in the present study. The likely explanation of this finding may be an increased production of angiotensinogen by abdominal adipose tissue, which is locally converted to angiotensin II, inducing an increase in peripheral vascular resistance and $\mathrm{BP}^{(62)}$

The present study has some limitations. First, the sample size was small; however, it is noteworthy that the cohort consisted of low-income women, mothers of malnourished children, which was a very specific group. The small sample size may have reduced the statistical power of the analyses. In some cases, such as the difference between baseline and final energy intake and the association between the number of meals and weight gain, clinically important findings may have been missed, possibly due to the lack of power. Second, we assessed TEE and PAL only at the end of the follow-up period, and we could not assess the entire cohort, affecting the statistical analyses. Third, dietary intake data were assessed using only the $24 \mathrm{~h}$ recall method, which is known to underestimate energy intake due to under-reporting.

In conclusion, the present study shows that even when eating in a reasonably balanced manner (i.e. without high consumption of energy or high-glycaemic index and ultraprocessed foods), low-income short-statured women, mothers of malnourished children, gain weight and develop obesityrelated co-morbidities. Sedentary behaviour and reduced PAL exhibited by these women partially explained their weight gain. In addition, they exhibited a low TEE when compared with similar cohorts of adult women from better socio-economic conditions. It is possible that the women in the present study exhibited physiological adaptive mechanisms (e.g. low energy expenditure and decreased thyroid hormone levels), resulting from insults in early life. However, the observational nature of the present study prevents the deduction of any direction of causality. Future research should focus on metabolic mechanisms that are involved in weight gain in low-income individuals.

\section{Acknowledgements}

The present study was supported by the Conselho Nacional de Desenvolvimento Científico e Tecnológico (CNPq, grant no. 552194/2011-5). The sponsor had no role in the design and analysis of the study or in the writing of this article.

The authors' contributions are as follows: T. M. M. T. F., A. L. S. and E. F. conceived the idea; N. B. B. and A. P. G. C. conducted the statistical analyses; R. P. A. B. and F. C. A. A. collected the data. All authors wrote and approved the final version of the manuscript.

The authors declare that they have no conflicts of interest.

\section{References}

1. Victora CG, Adair L, Queda C, et al. (2008) Maternal and child undernutrition: consequences for adult health and human capital. Lancet 371, 340-357.

2. Drenowsky A (2009) Obesity, diets and social inequality. Nutr Rev 67, S36-S39.

3. Oddo VM, Rah JH, Semba RD, et al. (2012) Predictors of maternal and child double burden of malnutrition in rural Indonesia and Bangladesh. Am J Clin Nutr 95, 951-958.

4. Gardner DS \& Rhodes P (2009) Developmental origins of obesity: programming of food intake or physical activity? Adv Exp Med Biol 646, 83-93.

5. Barbosa JM, Cabral PC, Lira PIC, et al. (2009) Fatores socioeconômicos associados ao excesso de peso em populações de baixa renda do Nordeste Brasileiro (Socioeconomic factors associated with overweight in low-income populations in Northeast Brazil). Arch Latin Amer Nutr 59, 22-29.

6. Enes CC \& Slater B (2010) Obesidade na adolescência e seus principais fatores determinants (Obesity in adolescence and its main determinants). Rev Bras Epidemiol 13, 163-171.

7. Clemente APG, Santos CDL, Martins VJB, et al. (2011) Mild stunting is associated with higher body fat: study of a low-income population. J Pediatr 87, 138-144.

8. Pereira MA (2006) The possible role of sugar-sweetened beverages in obesity etiology: a review of the evidence. Int $J$ Obes 30, S28-S36.

9. Monteiro CA, Benicio MH, Konno SC, et al. (2009) Causes for the decline in child undernutrition in Brazil, 1996-2007. Rev Saude Publ 43, 35-43.

10. Larsson SC, Akesson A \& Wolk A (2014) Sweetened beverage consumption is associated with increase risk of stroke in women and men. J Nutr 144, 856-860.

11. Murphy NJ, Schraer CD, Thiele MC, et al. (1995) Dietary change and obesity associated with glucose intolerance in Alaska Natives. J Am Diet Assoc 95, 676-682.

12. Compher C (2006) The nutrition transition in American Indians. J Transcult Nurs 17, 217-223.

13. Esfahani A, Wong JMW, Mirrahimi A, et al. (2009) Glycemic index: physiological significance. J Am Coll Nutr 28, 439S-445S.

14. Westman EC, Feinman RD, Mavropoulos JC, et al. (2007) Low-carbohydrate nutrition and metabolism. Am J Clin Nutr 86, 276-284.

15. Popkin BM, Adair LS \& Ng SW (2012) Global nutrition transition and the pandemic of obesity in developing countries. Nutr Rev 70, 3-21.

16. Lillycrop KA \& Burdge GC (2012) Epigenetic mechanisms linking early nutrition to long term health. Best Pract Res Clin Endocrinol Metab 26, 667-676. 
17. Said-Mohamed R, Bernard JY, Ndzana AC, et al. (2012) Is overweight in stunted preschool children in Cameroon related to reductions in fat oxidation, resting energy expenditure and physical activity? PLOS ONE 7, e39007.

18. Barker DJ (1995) Fetal origins of coronary heart disease. BMJ 311, 171-174.

19. Gluckman PD, Hanson MA \& Buklijas T (2010) A conceptual framework for the developmental origins of health and disease. J Dev Orig Health Dis 1, 6-18.

20. Aizer A \& Currie J (2014) The intergenerational transmission of inequality: maternal disadvantage and health at birth. Science 344, 856-861.

21. Florêncio TM, Ferreira HS, França APT, et al. (2001) Obesity and undernutrition in a very-low-income population in the city of Maceio, Northeastern Brazil. Br J Nutr 86, 277-284.

22. Ferreira HS, Moura FA, Cabral-Júnior CR, et al. (2009) Short stature of mothers from an area endemic for undernutrition is associated with obesity, hypertension and stunted children: a population-based study in the semi-arid region of Alagoas, Northeast Brazil. Br J Nutr 101, 1239-1245.

23. Brazilian Institute of Geography and Statistics (2009) Household Budget Survey 2008-2009: Analysis of Food and Personal Consumption in Brazil. Rio de Janeiro: Brazilian Institute of Geography and Statistics.

24. Florêncio TT, Ferreira HS, Cavalcante JC, et al. (2007) Short stature, abdominal obesity, insulin resistance and alterations in lipid profile in very low-income women living in Maceió, North-east Brazil. Eur J Cardiovasc Prev Rehabil 14, 346-348.

25. Sawaya AL \& Martins PA (2003) Effects of childhood malnutrition on the increase of risk factors for obesity, non-insulin dependent diabetes mellitus and coronary heart disease, vol. 76, pp. 9-37. In Section of Nutritional and HealthRelated Environmental Studies - Division of Human Health. (Org.). Application of Nuclear Techniques in the Prevention of Degenerative Diseases (Obesity and Noninsulin Dependant Diabetes) in Ageing. Vienna: International Atomic Energy Agency.

26. Sichieri R, Silva CV \& Moura AS (2003) Combined effect of short stature and socioeconomic status on body mass index and weight gain during reproductive age in Brazilian women. Braz J Med Biol Res 36, 1319-1325.

27. Cunha DB, Almeida RMV, Sichieri R, et al. (2010) Association of dietary patterns with BMI and waist circumference in a low-income neighbourhood in Brasil. Br J Nutr 104, 908-913.

28. World Health Organization (2010) World Health Statistics 2010 Contains WHO's Annual Compilation of Data from its 193 Member States, and Includes a Summary of Progress Towards the Health-related Millennium Development Goals and Targets. Geneva: WHO.

29. Ministério da Saúde (2012) Vigitel Brasil: Vigilância de fatores de risco e proteção para doenças crônicas por inquérito telefônico (Vigitel Brazil: Risk Factors for Surveillance and Protection for Chronic Diseases Inquiry). Brasília: Ministério da Saúde.

30. World Health Organization (1998) The WHO Child Growth Standards. Geneva: WHO. http://www.who.int/ childgrowth/en/

31. Joint National Committee (1997) The sixth report of the Joint National Committee on the Prevention, Detection, Evaluation, and Treatment of High Blood Pressure (JNC-VI). Arch Intern Med 157, 2413-2446.

32. Matthews DR, Hosker JP, Rudenski AS, et al. (1985) Homeostasis model assessment: insulin resistance and $\beta$-cell function from fasting plasma glucose and insulin concentrations in man. Diabetologia 28, 412-419.

33. Friedewald WT, Levy RI \& Fredrickson DS (1972) Estimation of the concentration of low density lipoproteins cholesterol in plasma without use of the ultracentrifuge. Clin Chem 18, 499-502.

34. Zabotto CB, Vianna RPT \& Gil MF (1996) Registro fotográfico para inquéritos dietéticos: utensilio e porções (Photographic Record for Dietary Surveys: Utensil and Portions), 1st ed., 74 pp. Campinas: UNICAMP.

35. Institute of Medicine (2002) Dietary Reference Intakes for Energy, Carbohydrate, Fiber, Fat, Fatty Acids, Cholesterol, Protein and Amino Acids, Vitamin A, Vitamin K, Arsenic, Boron, Chromium, Copper, Iodine, Iron, Manganese, Molybdenum, Nickel, Silicon, Vanadium, Zinc, Vitamin C, Vitamin E, Selenium, and Carotenoids (Macronutrients). Washington, DC: National Academy Press.

36. Monteiro CA, Levy RB, Claro RM, et al. (2010) A new classification of foods based on the extent and purpose of their processing. Cad Saúde Pública 26, 2039-2049.

37. Food and Agriculture Organization \& World Health Organization (1998) Carbohydrates in Human Nutrition. Report of a Joint FAO/WHO Expert Consultation. FAO Food Nutr Pap 66, $1-140$.

38. Food and Agriculture Organization (2011) Guidelines for Measuring Household and Individual Dietary Diversity. Rome: FAO

39. Wong WW, Lee LS \& Klein PD (1987) Deuterium and oxygen-18 measurements on microliter samples of urine, plasma, saliva, and human milk. Am J Clin Nutr 45, 905-913.

40. Gigante DP, Horta BL, Lima RC, et al. (2006) Early life factors are determinants of female height at age 19 years in a population-based birth cohort (Pelotas, Brazil). J Nutr 136, 473-478.

41. Silventoinen K (2003) Determinants of variation in adult body height. J Biosoc Sci 35, 263-285.

42. Ferreira Hda D, Cesar JA, Assunção ML, et al. (2013) Time trends (1992-2005) in undernutrition and obesity among children under five years of age in Alagoas State, Brazil. Cad Saúde Pública 29, 793-800.

43. Ferreira HS, Albuquerque MF, Ataide TR, et al. (1997) Estado nutricional de crianças menores de dez anos residentes em invasão do "Movimento dos Sem-Terra", Porto Calvo, Alagoas (Nutritional status of children under ten years living in invasion of the "Movement of the Landless" Porto Calvo, Alagoas). Cad Saúde Pública 13, 137-139.

44. World Health Organization (2007) Growth Reference Data for 5-19 Years. Geneva: WHO

45. Dunn CE (2007) The intergenerational transmission of lifetime earnings: evidence from Brazil. $B E \quad J$ Econ Anal Policy 7.

46. Florêncio TT, Ferreira HS, Cavalcante JC, et al. (2003) Food consumed does not account for the higher prevalence of obesity among short-statured adults in a very-low-income population in the northeast of Brazil, Maceió-Alagoas. Eur J Clin Nutr 57, 1437-1446.

47. Clemente APG, Santos CD, Silva AAB, et al. (2012) A baixa estatura leve está associada ao aumento da pressão arterial em adolescentes com sobrepeso (The mild stunting is associated with increased blood pressure in overweight adolescents). Arq Bras Cardiol 98, 06-12.

48. Fernald LC, Gertler PJ \& Hou X (2008) Cash component of conditional cash transfer program is associated with higher body mass index and blood pressure in adults. J Nutr 138, $2250-2257$ 
49. Ministério da Saúde (2008) Guia alimentar para a população brasileira: Promovendo a alimentação saudável (Food Guide for the Brazilian Population: Promoting Healthy Eating), 1st ed., 210 pp. Brasilia: Ministério da Saúde.

50. Drewnowski A (1997) "Why do we like fat?". J Am Diet Assoc 97, S58-S62.

51. Drewnowski A \& Darmon N (2005) The economics of obesity: dietary energy density and energy cost. Am J Clin Nutr 82, 1 Suppl., 265S-273S.

52. Giskes K, Avendano M, Brug J, et al. (2010) A systematic review of studies on socioeconomic inequalities in dietary intakes associated with weight gain and overweight/obesity conducted among European adults. Obes Rev 11, 413-429.

53. Kulovitz MG, Kravitz LR, Mermier C, et al. (2014) Potential role of meal frequency as a strategy for weight loss and health in overweight or obese adults. Nutrition 30, 386-392.

54. Tremblay MS, LeBlanc AG, Kho ME, et al. (2011) Systematic review of sedentary behaviour and health indicators in school-aged children and youth. Int I Behav Nutr Phys Act 21, 8-98.

55. Scagliusi FB, Ferrioli E, Pfrimer K, et al. (2008) Underreporting of energy intake in Brazilian women varies according to dietary assessment: a cross-sectional study using doubly labeled water. J Am Diet Assoc 108, 2031-2040.

56. Sawaya AL, Tucker K, Tsay R, et al. (1996) Evaluation of four methods for determining energy intake in young and older women: comparison with doubly labeled water measurements of total energy expenditure. Am J Clin Nutr $\mathbf{6 3}$, 491-499.

57. Wong WW, Roberts SB, Racette SB, et al. (2014) The doubly labeled water method produces highly reproducible longitudinal results in nutrition studies. J Nutr 144, 777-783.

58. Wilson HJ, Dickinson F, Hoffman DJ, et al. (2012) Fat free mass explains the relationship between stunting and energy expenditure in urban Mexican Maya children. Ann Hum Biol 39, 432-439.

59. Kok P, Roelfsema F, Langendonk JG, et al. (2005) High circulating thyrotropin levels in obese women are reduced after body weight loss induced by caloric restriction. J Clin Endocrinol Metab 90, 4659-4663.

60. Hoffman DJ, Roberts SB, Verreschi I, et al. (2000) Regulation of energy intake may be impaired in nutritionally stunted children from the shantytowns of São Paulo, Brazil. J Nutr 130, 2265-2270.

61. Hoffman DJ, Sawaya AL, Verreschi I, et al. (2000) Why are nutritionally stunted children at increased risk of obesity? Studies of metabolic rate and fat oxidation in shantytown children from São Paulo, Brazil. Am J Clin Nutr 72, 702-707.

62. Wajchenberg BL (2000) Subcutaneous and visceral adipose tissue: their relation to the metabolic syndrome. Endocr Rev 21, 697-738. 